\title{
Intellectual Capital and Its Impact on Financial Performance: A Study of Oil and Gas Sector of Pakistan
}

\author{
Muhammad Arslan*, Rashid Zaman \\ Bahria University Islamabad, PO box 44000, E-8, Islamabad, Pakistan \\ *E-mail address: MuhammadArslan73@gmail.com
}

\begin{abstract}
The study examines the Intellectual Capital (IC) performance of oil and gas sector of Pakistan over the period of 2007 to 2011 and its impact on corporate financial returns. The study uses value added intellectual coefficient (VAICit ${ }^{\mathrm{TM}}$ ) to measure IC performance and its various components of VAICit ${ }^{\mathrm{TM}}$ like (HCEit, SCEit and CEEit) and its impact on financial performance (ROEit, ROIit and EPSit). Micro panel data of oil and gas sector registered in KSE-100 index is collected from their consolidated annual reports over the period of 2007 to 2011. The IC performance is measured by Ante Pulic Model (VAICit ${ }^{\mathrm{TM}}$ ) and its effect on corporate returns (ROEit, ROIit and EPSit) is tested by Random Effect Model estimation. Hausman test suggests that study accepts null hypothesis (Chi2. Prop $>0.05$ ) where for ui is uncorrelated with regressor means that random effect is preferred versus alternative fixed effect in all the proposed research models. The study reveals that VA is considered an important component for measuring the VAICit ${ }^{\mathrm{TM}}$ performance and it has positive and significant relationship with firm's profitability (EPSit) and HCEit and SCEit have positive and significant relationship with firm's financial performance (ROEit and ROIit) respectively. So, this study explores that Intellectual Capital Efficiency (ICE) has relatively larger contribution for measuring the VAICit ${ }^{\mathrm{TM}}$ performance where HCEit and SCEit execute substantive role to accelerate the financial performance of oil and gas sector of Pakistan as compare to tangible assets.
\end{abstract}

Keywords: Intellectual Capital; Financial Performance; Financial Performance; Oil and Gas sector, Pakistan

\section{INTRODUCTION}

Prominently, many practitioners, academicians and researchers consider intellectual capital (IC) as a key determinant to enhance value creation efficiency and firm performance. The growing importance of IC in all sectors of economy led the new directions in knowledge base economy especially in oil and gas sector. Oil and gas sector is very crucial for Pakistan's economy and its importance cannot be overlooked due to growing energy crises. This sector has been phenomenal since 1947. It has played a significant role in development of national GDP whereas Pakistan is meeting about $18 \%$ of its oil demands from its local resources.

The present growth rate of economy shows that our oil demands will be from 64.5 million tons in 2010-11 to over 361.31 million tons in 2030. Over the last 3 to 4 decades, the gas sector has played a significant role by making large indigenous discoveries. But due to growing population and industrial needs this sector would not remain self-sufficient. Pakistan 
has large number of reservoirs of oil and gas but it requires a massive foreign and local investment for the extraction, exploration and refinery of these valuable resources. The growth of knowledge management has enhanced the importance of IC, therefore, many organizations similar to energy sector consider IC as a main driver of growth, value creation and competitive advantage in knowledge base economy (Cabrita and Vaz, 2006). The World Bank (1998, p. 1) has identified the importance of knowledge and intellectual ability: "Knowledge is like light. Weightless and intangible, it can easily travel the world, enlightening the lives of people everywhere". There has been great evidence for the last couple of decades that economies are shifting themselves to knowledge generation activities where knowledge creation, sharing, and dissemination is the main constituent for organizational growth and survival (OECD, 1996). Such activities in knowledge base economy put great emphasis on the management of the human capital efficiency through training and knowledge sharing. Therefore, the aim of present study is to examine and assess the IC performance in oil and gas sector of Pakistan and its impact on financial returns. This study also examines the consequent effect of IC on firm's performance and gives deep insights how important IC is especially the human capital investment for this sector to reduce energy crises.

\section{LITERATURE REVIEW}

The empirical literature reveals that IC has positive and significant impact on future performance of firms. Tan, Plowman and Hancock (2007) measure the empirical relation of IC with present and future performance of firms using VAICTM model and show that IC has positive and significant association with growth rate and future performance of firms where IC's contribution to firm's performance varies industry to industry. IC is considered as one of the most important valuable strategic asset for firms. The success and competiveness of firms are based on management of these strategic assets like human capital, structural capital, relational capital etc. Tseng and Goo (2005) analyze that organizational success is based on the efficient management of knowledge based assets that is intellectual assets therefore IC has positive relationship with present and future corporate value of firm in knowledge base economy (Pew et al. 2007). Cabrita and Vaz (2005) examine the empirical relationship of IC with bank's performance. They also find that human capital, structural capital and relational capital have substantive relationship with bank's performance where IC is considered a key indicator for measuring the value creation efficiency of banks. Goh (2005) explores the pragmatic findings while measuring the intellectual capital efficiency of Malaysian commercial banks based on VAICTM assessment and found that 80 percent efficiency in VAIC $^{\text {TM }}$ performance is attributed by Human Capital Efficiency (HCE) which means that HCE has relatively larger contribution in measuring VAIC ${ }^{\text {TM }}$ performance as compare to SCE and CEE. Same findings are revealed by Joshi, Cahill and Sidhu (2010) where VAIC ${ }^{\text {TM }}$ has positive and significant relationship with $\mathrm{HC}$ to enhance the value creation efficiency of Australian Owned banks. This study also explored that HCE was a major determinant for measuring the VAIC ${ }^{\mathrm{TM}}$ performance of banks as compare to SCE and CEE and same findings are explored by (Mohiuddin et al., 2006, Calisir et al., 2010). Maditinos et al., (2011) found that human capital Efficiency (HCE) has significant relationship with financial performance (ROA). So, investment on human capital is more returnable as compare to SCE and CEE (Goh 2005; Joshi et el., 2010; Laing et al., 2010; Calisir et al., 2010; Rehman et al., 2011) where HCE has extensive contribution in measuring VAIC ${ }^{\text {TM }}$ performance and has a positively significant relationship with financial performance. 
As a result, companies are conducting a substantive investment on human capital to upgrade the stock of $\mathrm{HC}$ through employee training and knowledge sharing. Therefore, human capital is more significant and vital than structural and physical assets (Kamath 2008). Furthermore, HCE is the most significant variable and it has positive and significant association with both profitability and productivity of pharmaceutical industry of India. Yalma and Coskun (2007) find the empirical relationship to measure the intellectual capital performance of banks listed in Istanbul Stock Exchange and asserted that VAIC ${ }^{\text {TM }}$ has positive relationship with profitability of banks. Diez et al., (2010) examine the statistical significant and positive relationship between intellectual capital efficiency and increased value creation (sales growth) in Spanish firms where human and structural capital is positively associated with sales growth.

\section{INTELLECTUAL CAPITAL}

A brief review of contemporary research identifies that IC has been used as an intangible and knowledge base asset. Therefore, a sustainable firm performance and competitive advantage is mainly associated with these knowledge base assets, firm's intellectual capabilities and resources which that jointly referred as IC (Bontis 1998, 2001; $\mathrm{Wu}$ et al., 2006). The growing phenomena of IC have been realized by too many contemporary researchers and policy makers that organization's success and survival is based on human capabilities, experience and their skill, innovation process and technology (Stewart, 1997, 2001; Sveiby, 1997). Stewart (1997) defines the IC as valuable intellectual asset which is the core competency to enhance the growth of organization. Edvinsson and Malone (1997) defined IC as knowledge that can be transformed to generate value. Porter (1999) argue the success of any organization in competitive environment is the employment of intellectual resources.

However, the firm future performance and profitability is based on IC and human intellectual abilities rather physical and tangible assets (Wood, 2003; Hazlina and Zubaidah, 2008). The term IC and intangible assets are interchangeable to each other therefore; they are considered as an integral part of organization's success that may constitute 80 percent in market value creation (Fornell, 2000). Stewart (1997) defines the IC as valuable intellectual assets which are the core competencies to lead the growth of organization. The increasingly importance of IC has recognized it as valuable strategic asset for firm's sustainable performance in a competitive advantage (Maditinos et al., 2011). IC is considered a driving force to gain competitive edge in dynamic environment of globalization which has positive relationship with firm performance (Tovstiga and Tulugurova 2007). Makki and Lodhi (2008) analyze that firm's intellectual capital efficiencies are determined by their profitability.

In many organizations the knowledge management and intellectual resources are very important for proven growth of these organizations (Boedker et al., 2005). For stock and stake holders, it is vital to effectively manage the intellectual as well as knowledge base resources. The prime objective of this study is to measure the intellectual capital performance and to examine the empirical relationship of IC performance constituents with financial performance indicators. The methodology of study is similar with Tan et al., (2007); Goh (2005); Joshi et al., (2010); Mohiuddin et al., (2006); Firer and Williams (2003); Rehman et al., (2011); Kamath (2008); Maditinos et al., (2011) etc. Based on value added intellectual coefficient (VAIC $^{\text {TM}}$ ), this study analytically examines VAIC ${ }^{\text {TM }}$ performance and components Human Capital Efficiency (HCE), StructuralCapital Efficiency (SCE) and Capital Employed 
Efficiency (CEE) and its relationship with financial performance indicators (ROA, REO and EPS). Sveiby (1997) classifies the IC into three major components.

\section{Human Capital \\ 2. Structural Capital \\ 3. Relational Capital}

\section{1. Human Capital}

Human capital is one the valuable strategic asset. It has enormous contribution in the field of inventions and innovation therefore, its importance cannot be overlooked in the knowledge base economy. There has been a growing attention that manpower is considered as an essential resource for organization success and survival which deliver basis for competitive advantage in dynamic business environment. These are the intellectual abilities of organizations' top management being used for making strategic decisions. HC is the knowledge, experience, skill and expertise of firms' employees (Edvinsson and Malone 1997). Diez, Ochoa, Prieto and Santidrian (2010) define HC as firm's competencies and value creation efficiencies which are linked by employee's knowledge, skill and intellectual capabilities. Sveiby (1997) describes HC as abilities to work in different dimension that enhance value creation both in tangible and intangible assets. Finally, HC defines as combined capabilities of firms' employees which are extracted to find out paramount solutions of structured and unstructured problems from the knowledge, experience and skill of individuals (Bontis 1998). HC is considered as one of the integral part of IC and it has a very deep concern with IC and as well as firms' performance (Marques and Simon 2003) and define HC as technical knowledge, experience, Team spirit and leadership abilities of firms' management.

\section{2. Structural Capital}

Structural Capital is second integral part of IC. It refers to innovative process, technology, databases, patents and copy rights and supportive infrastructure process that enable human capital to function properly. SC identifies organizations' processes, technology and supportive activities to link for value creation efficiency of firm (Carroll and Tansey 2000). So, it is a very key mechanism for transmission and communication of knowledge in internal and external environment of organization for value creation.

\section{3. Relational Capital}

The relational capital is recognized as the relationships with customers, suppliers and stakeholders that influence the company's life. Cheng et al (2010) argues that customer relations are a crucial factor in competitive advantage which result an increase of corporate performance. Prahalad and Ramaswamy (2000) found that the customers are the source to increase the competency of organizations. Increase of organizational competency is based on customer's relations.

\section{THEORETICAL FRAMEWORK}

After review of extensive literature, the study addresses the following theoretical frame works. 


\section{Theoretical Framework 1}

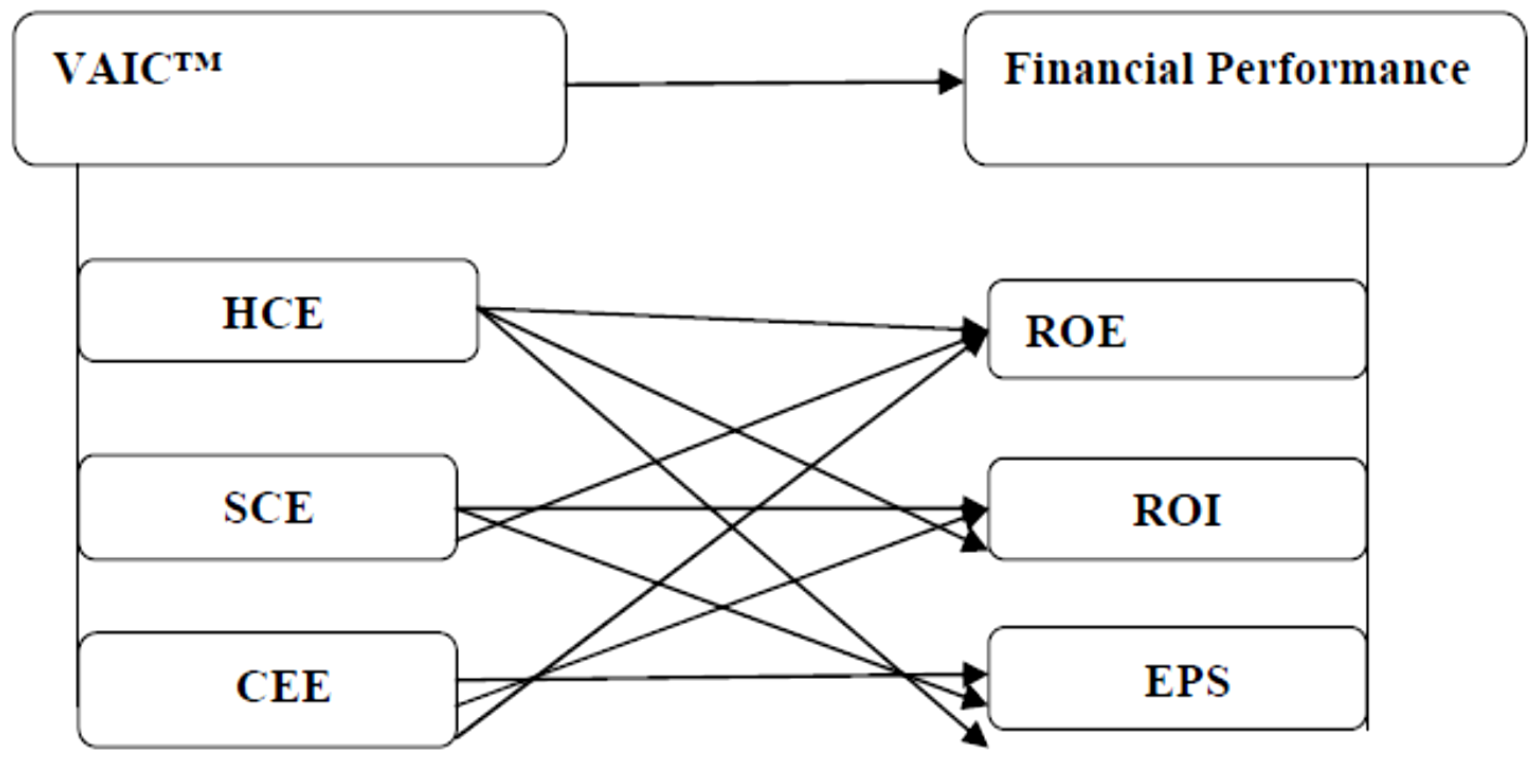

Theoretical Framework 2

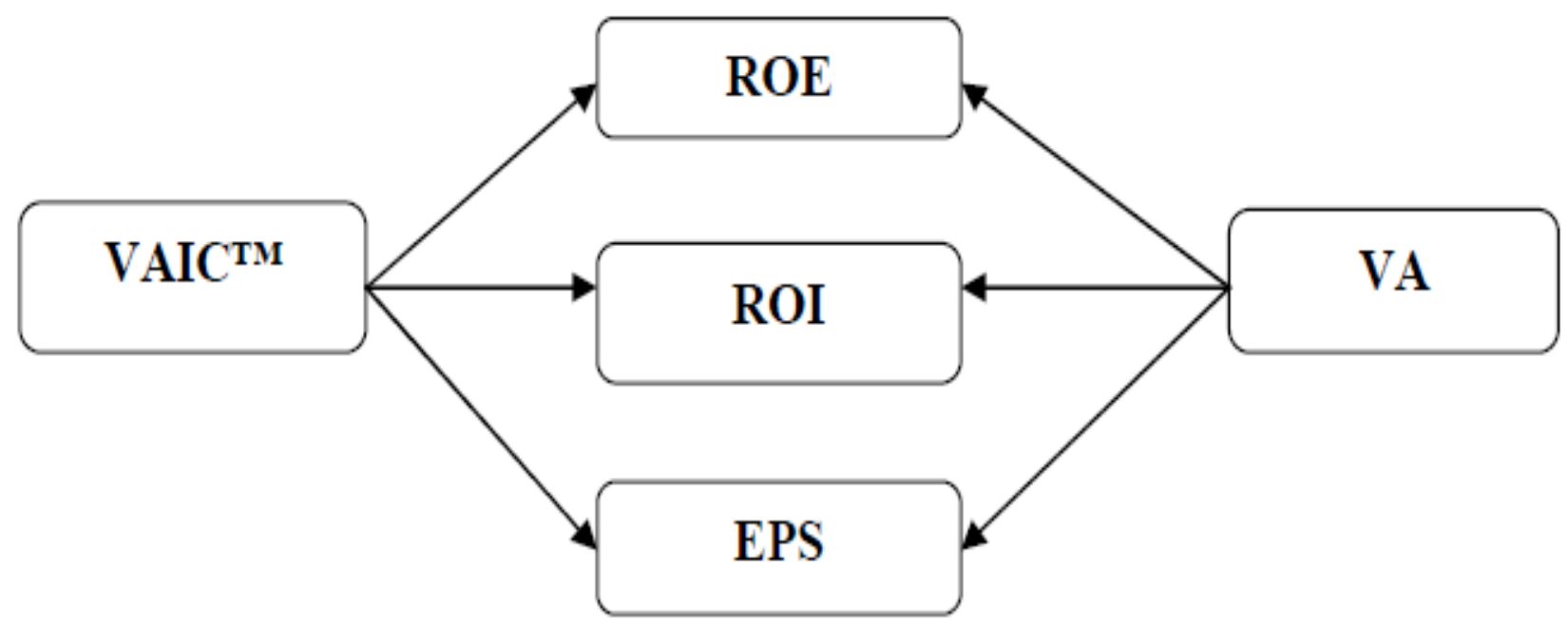

Hypothesis:

After review of plethora of literature and Ante Public model, the current research paper addresses the following proposed hypothesis; 
H1a: There is a significant and positive association between Human Capital Efficiency (HCE) and financial performance indicator (ROE).

H1b: There is a significant and positive association between Structural Capital Efficiency (SCE) and financial performance indicator (ROI).

H1c: There is a significant and positive association between Capital Employed Efficiency (CEE) and financial performance indicator (EPS).

H1d: There is a significant and positive association between VAICTM and financial performance indicators (ROE, ROI and EPS).

H1e: There is a significant and positive association between VA and financial performance indicators (ROE, ROI and EPS).

\section{DATA COLLECTION AND METHODOLOGY}

\section{1. Data}

Data is collected from 9 companies registered in KSE-100 index under the umbrella of oil and gas sector. Micro panel data is gathered and assembled from annual reports and its relevant websites, Karachi Stock Exchange and companies offices over the period of 2007 to 2011.

\section{2. Value Added Intellectual Coefficient (VAICTM) Ante Pulic Model}

VAIC TM model is the most modern approach for measuring and evaluating the performance of intangible and tangible assets. It is a very consistent and valid technique for measuring the performance of intangible assets that is Intellectual Capital Efficiency (ICE) which is the composition of human and structural capital efficiency. VAIC ${ }^{\text {TM }}$ also measures and evaluates the efficiency of physical and financial assets. This methodology is developed by Ante Pulic $(1988,2000)$ in Austrian Research Centre of IC. Therefore, it is also recognized as Austrian approach.

Pulic hasused this approach into its various studies Ante Pulic (1997, 1998, 2001 and 2002). Many researchers and practitioners used this methodology for measuring IC performance like Firer and Williams 2003; Riahi-Belkauui 2003; Mavridis 2004; Goh 2005; Goo and Tseng 2005; Mavridis 2005; Kujansivu and Lonnqvist 2005; Mohiuddin, Najibullah and Shahid 2006; Ji-jian, Nai-ping and Yu-sheng 2006; Tan, Plowman and Hancock 2007; Pew et al.2007; Yalama and Coskun 2007; Kamath 2007 and 2008; Gan and Saleh 2008; Makki, Lodhi and Rahman 2008; Ting and Lean 2009; Muhammad and Ismail 2009; Kamukama, Ahiauzu and Ntayi 2010 and 2011; Zeghal and Maaloul 2010; Laing, Dunn and Lucas 2010; Joshi, Cahill and Sidhu 2010; Diez et al. 2010; Ahangar 2011; Maditinos et al. 2011, Rehman et al., $(2011,2012)$ etc. VAICTM is designed to provide information regarding the value creation efficiencies of bot tangible and intangible assets. So, this model is briefly given below with its intellectual coefficients.

- $\quad$ Output $=$ Total Sale

- $\quad$ Input $=$ Operating expenses (Input referred to all the operating expenses which are used to generate the sale other than personal costs).

- $\quad$ Value added = Output-Input (VA referred to Output minus Input which is measured to determine value added efficiency of firms'). 
- $\quad \mathrm{HC}=$ Personal cost (Salaries and Wages), considered as an investment.

- $\mathrm{HCE}=\mathrm{VA} / \mathrm{HC}$ (Human Capital Efficiency referred to per unit of value of human capital)

- $\quad \mathrm{CA}=($ Capital invested in physical and financial capital).

- $\quad \mathrm{CEE}=\mathrm{VA} / \mathrm{CA}$ (Capital Employed Efficiency referred to per unit value of physical and financial assets).

- $\quad \mathrm{SC}=\mathrm{VA}-\mathrm{HC}$

- $\quad \mathrm{SCE}=\mathrm{SC} / \mathrm{VA}$ (Structural Capital Efficiency referred to per unit value of structural capital).

- $\quad$ VAIC ${ }^{\mathrm{TM}}=\mathrm{HCE}+\mathrm{SCE}+\mathrm{CEE}$ (Value Added Intellectual Coefficient)

Table No. 1

\begin{tabular}{|c|c|c|c|c|c|}
\hline Sr.\# & Oil and Gas Sector & $\begin{array}{c}\text { VAICTM Performance } \\
\text { (Rs.) } \\
\end{array}$ & $\begin{array}{l}\text { VAICTM } \\
\text { Ranking } \\
\end{array}$ & $\begin{array}{l}\text { VA (Rs. } \\
\text { Millions) }\end{array}$ & $\begin{array}{c}\text { VA- } \\
\text { Ranking }\end{array}$ \\
\hline 1 & Pakistan Refinery Ltd (PRL) & 4497.8808 & 1 & $430,956,933$ & 4 \\
\hline 2 & Attock Refinery Ltd (ARL) & 3081.44958 & 2 & $344,156,569$ & 7 \\
\hline 3 & Attock Petroleum Ltd (APL) & 2749.21754 & 3 & $702,668,873$ & 3 \\
\hline 4 & National Refinery Ltd (NRL) & 2747.05936 & 4 & $123,623,116$ & 9 \\
\hline 5 & Pakistan State Oil (PSO) & 1213.93791 & 5 & $420,597,257$ & 5 \\
\hline 6 & Shell Pakistan Ltd & 691.586076 & 6 & $3,536,352,511$ & 1 \\
\hline 7 & Mari Gas company Ltd & 230.925102 & 7 & $401,207,734$ & 6 \\
\hline 8 & $\begin{array}{l}\text { Oil and Gas Development Co. } \\
\text { Ltd (OGDC) }\end{array}$ & 80.1626756 & 8 & $199,517,289$ & 8 \\
\hline 9 & Pakistan Petroleum Ltd (PPL) & 78.6211303 & 9 & $904,808,901$ & 2 \\
\hline
\end{tabular}

\section{3. Five Year VAICTM and VA Performance and their Ranking}

The Table 1 shows the five year VAIC TM and VA performance and its ranking. The purpose of ranking is to access the five year performance of IC in oil and gas sector based on Ante Pulic model. Value Added Intellectual Coefficient (VAIC ${ }^{\text {TM}) ~ i s ~ a ~ k e y ~ m e t h o d o l o g y ~ f o r ~}$ measuring the IC performance. The features of this methodology that it not only evaluates the performance of intangible assets (i.e. Intellectual Capital Efficiency (ICE) which composition of Human Capital Efficiency and Structural Capital Efficiency) but it also evaluates the performance of tangible assets consist of Capital Employed Efficiency (CEE). So, VAIC ${ }^{\text {TM }}$ is the composition human capital, structural capital and capital employed which provides the information about the company value creation efficiency of both tangible and intangible assets.

The Table 1 shows that each company is ranked based on VAICTM performance. So, Pakistan Refinery Ltd (PRL) is the most efficient company based on five year VAIC TM performance. It has generated the value of (VAIC ${ }^{\mathrm{TM}}=$ PKR-3754.05817) over the period of 2007 to year 2011. This means that if we invest five PKR on company it would generate value of PKR 3754.05817 over the five and it is ranked at $1^{\text {st }}$ position being a most efficient 
company in oil and gas sector. Followed by Attock Refinery Ltd (ARL) and Attock Petroleum Ltd (APL) where VAIC TM performance is PKR-3081.44958 and PKR-2749.21754 and placed at $2^{\text {nd }}$ and $3^{\text {rd }}$ position respectively. Whereas the, Pakistan Petroleum Ltd (PPL) is ranked at $9^{\text {th }}$ position being the least efficient company in oil and gas sector. It has generated the value of PKR-78.6211303 over the five year. Table 1 also shows five year VA performance in oil and gas sector. Five year (VA) performance is calculated by summing up each year (VA) performance. Pakistan Refinery Ltd (PRL) is the most efficient company based on VAICTM but it is ranked at $4^{\text {th }}$ position VA performance. It has generated Rs. Millions $430,956,933 /$. Attock Refinery Ltd (ARL) is the second most efficient company based on VAICTM performance but it is ranked at $7^{\text {th }}$ position based on VA. Shell Pakistan Ltd is placed at $6^{\text {th }}$ position based on VAIC ${ }^{\text {TM }}$. It is the most efficient company based on VA and it is ranked at $1^{\text {st }}$ position. So, Attock Petroleum Ltd (APL), Pakistan Refinery Ltd (PRL), Pakistan State Oil (PSO), Mari Gas Company Ltd, Attock Refinery Ltd (ARL), Oil and Gas Development Co. Ltd (OGDC) and National Refinery Ltd (NRL) are placed at 3rd, 4th, 5th, 6th, 7th, 8th and 9th position respectively based on VA performance.

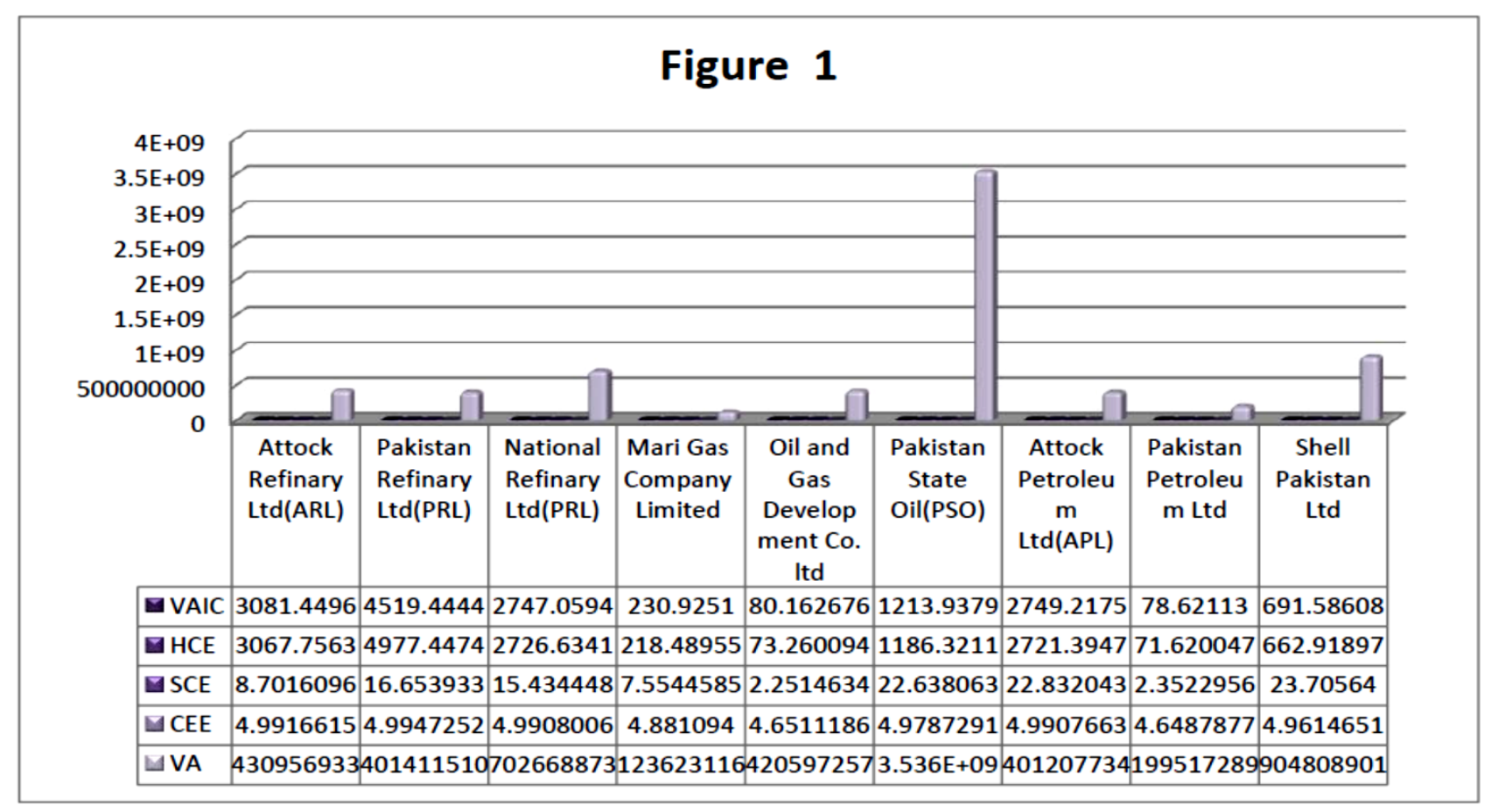

This shows that Pakistan Refinery Ltd being the most efficient company based on VAICTM performance where HCE performs substantial contribution for measuring the VAIC $^{\text {TM }}$ performance as compare to other components of VAIC ${ }^{\mathrm{TM}}$. The justification is firm's that have potential stock of valuable knowledge asset that is human capital means better performance of IC to accelerate the financial returns.

\section{4. Econometric Methodology for Panel Data}

The panel data which is also known as longitudinal or cross-sectional data. In panel data, the behavior of entities is measured which varies across the time. The micro penal data is collected from 9 companies belong to oil and gas sector which have relative large market 
capitalization or trading volume in Karachi Stock Exchange for last 10 years. The data is collected and gathered from consolidated audited annual reports, relevant websites and OGRA (Oil and Gas Regulatory Authority) over the period of 2007 to 2011. Random Effects Model (REM) is used to measure the empirical relationship between VAICTM and its constituents i.e. (HCE, SCE and CEE) with financial performance indicators (ROE, ROI and EPS). The selection of random effects model is based on Hausman test justifications.

\section{Panel Data Equation}

$$
\text { Yit }=\beta 0+\beta 1 \times i t 1+\ldots \ldots \ldots \ldots . . . \beta k x i t+u i t
$$

\section{5. Hausman Specification Test for Fixed versus Random Effects Model}

A Hausman test is used to differentiate between random and fixed effects model (Hausman, 1978; Greene 1997). The Hausman test suggests where the null hypothesis preferred model is random effects versus alternative fixed effects to determine whether $\boldsymbol{u} \boldsymbol{i}$ are correlated or uncorrelated with regressors.

The null hypothesis of Huaman test for $\boldsymbol{u} \boldsymbol{i}$ is uncorrelated with regressors. The results of study indicate in the all the proposed research models that (Chi2. Prop $>0.05)$. So, study accepts the null hypothesis which means that random effects model is preferred. The justification behind the use of random effects is that variations across the entities are assumed to be random or uncorrelated with predictor and independent variables.

The equation for random effects models can be written as follows:

1) ROEit $=\beta \mathrm{VA} i t+\alpha+\mathrm{u} i t+\varepsilon i t$

2) ROIit $=\beta$ VAit $+\alpha+\mathrm{u} i t+\varepsilon i t$

3) EPSit $=\beta \mathrm{VAit}+\alpha+\mathrm{u} i t+\varepsilon i t$

4) ROEit $=\beta\left(\mathrm{VAIC}^{\mathrm{TM}}\right.$ it $)+\alpha+\mathrm{u} i t+\varepsilon i t$

5) ROIit $=\beta($ VAICit $)+\alpha+\mathrm{u} i t+\varepsilon i t$

6) EPSit $=\beta\left(\mathrm{VAIC}^{\mathrm{TM}}\right.$ it $)+\alpha+\mathrm{u} i t+\varepsilon i t$

7) ROEit $=\beta 1(\mathrm{HCE} i t)+\beta 2(\mathrm{SCE} i t)+\beta 3(\mathrm{CEE} i t)+\alpha+\mathrm{u} i t+\varepsilon i t$

8) EPSit $=\beta 1(\mathrm{HCE} i t)+\beta 2(\mathrm{SCE} i t)+\beta 3(\mathrm{CEE}$ it $)+\alpha+\mathrm{u} i t+\varepsilon i t$

9) EPSit $=\beta 1(\mathrm{HCE} i t)+\beta 2(S C E i t)+\beta 3(\mathrm{CEE} i t)+\alpha+\mathrm{u} i t+\varepsilon i t$

where,

ai $(I=1 \ldots . . n)=$ the unidentified intercept/cut off for the each company. ROEitROIit and

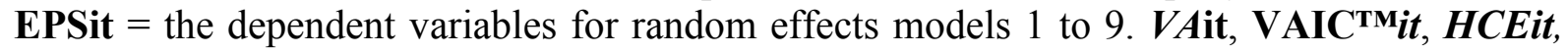
SCEit and $\boldsymbol{C E E i t}=$ independent variable(s) for random effects models 1 to 9.

$\boldsymbol{I}=$ Company and $\boldsymbol{t}=$ time. $\boldsymbol{\beta}$ is coefficient(s), and $\boldsymbol{u}$ it is the error term between the entity, $\boldsymbol{\varepsilon i t}$ within the entity error "In the case of time-series cross-sectional data, the interpretations of the beta coefficients would be" for a known company, as (VA), (VAIC TM), HCE, SCE and $C E E$ changes across the time by one unit, ROE, ROI and EPS increases or decreases by $\beta$ units. The rational for selection of random effect model that variations across the entities are assumed to be random and uncorrelated with the predictor or independent variable. 


\section{RESULTS AND ANALYSIS}

\begin{tabular}{|c|c|c|c|c|c|c|c|c|c|}
\hline \multicolumn{10}{|c|}{ Table No. 2} \\
\hline \multirow{2}{*}{$\begin{array}{c}\text { Dependent } \\
\text { Independent }\end{array}$} & \multicolumn{3}{|c|}{ ROEit } & \multicolumn{3}{|c|}{ ROIit } & \multicolumn{3}{|c|}{ EPSit } \\
\hline & M1 & M2 & M3 & M1 & M2 & M3 & M1 & M2 & M3 \\
\hline Constant & 1.751921 & 1.337056 & -0.139367 & 3.780809 & 1.542411 & -0.777253 & -0.487005 & 0.996595 & 0.779821 \\
\hline VAit & 0.8104 & & & $0.0769 * *$ & & & $0.0845 * * *$ & & \\
\hline VAICTMit & & 0.4475 & & & $0.0575^{* *}$ & & & $0.0110^{* *}$ & \\
\hline HCEit & & & $0.0233^{* *}$ & & & $0.0499 * *$ & & & 0.3739 \\
\hline SCEit & & & $0.0465 * *$ & & & 0.2027 & & & $0.0773 * *$ \\
\hline CEEit & & & $0.0100^{*}$ & & & 0.0064* & & & 0.3588 \\
\hline $\mathbf{R}^{2}$ & 0.00138 & 0.013799 & 0.168439 & 0.073239 & 0.082142 & 0.256585 & 0.068991 & 0.136715 & 0.206099 \\
\hline Adj. $\mathbf{R}^{2}$ & -0.0218144 & -0.009136 & 0.107593 & 0.051686 & 0.060797 & 0.202189 & 0.04734 & 0.116639 & 0.148009 \\
\hline F- Statistic & 0.059409 & 6.61 & 2.768281 & 3.39814 & 3.848221 & 4.716968 & 3.18645 & 6.809763 & 3.547915 \\
\hline Prob. (F-Stat) & 0.808591 & 0.132 & $0.053771 * * *$ & $0.072169^{* * *}$ & $0.05629^{* * *}$ & $0.006424 *$ & $0.081306^{* * * *}$ & $0.012424 * *$ & $0.022550 * *$ \\
\hline \multirow[t]{3}{*}{ Coefficients } & \begin{tabular}{|c|}
-0.033898 \\
\end{tabular} & 0.065707 & 0.468245 & 0.072169 & -0.222645 & 0.516642 & 0.245322 & 0.21545 & 0.173647 \\
\hline & & & \begin{tabular}{|l|}
0.706156 \\
\end{tabular} & & & 0.573052 & & & 0.605685 \\
\hline & & & -42.50043 & & & \begin{tabular}{|l|}
-58.34709 \\
\end{tabular} & & & -14.22242 \\
\hline \multirow[t]{3}{*}{ T-Statistics } & -0.241443 & 0.766587 & 2.356503 & 2.509336 & -1.952052 & 2.02014 & 1.76588 & 2.658933 & 0.899035 \\
\hline & & & 2.05335 & & & 1.294653 & & & 1.811858 \\
\hline & & & -2.695544 & & & -2.87521 & & & -0.927986 \\
\hline Durbin Wats on & 0.691792 & 0.705993 & 0.904998 & 0.760047 & 0.772567 & 1.059664 & 1.481002 & 1.687753 & 1.964228 \\
\hline $\begin{array}{l}\text { Haus man } \\
\text { Chi Sq. Statis tics }\end{array}$ & 2.552532 & 0.00002 & 2.566598 & 0.43799 & 1.282217 & 3.576149 & 0.080777 & 3.779143 & 6.405457 \\
\hline Haus man & $0.1101>0.05$ & $0.9965>0.05$ & $0.4634>0.05$ & $0.051>0.05$ & $0.2575>0.05$ & $0.311>0.05$ & $0.7762>0.05$ & $0.0519>0.05$ & $0.0935>0.05$ \\
\hline \multirow[t]{2}{*}{ (Prob.) } & (Reject Null & (Reject Null & (Reject Null & (Reject Null & (Reject Null & (Reject Null & (Reject Null & (Reject Null & (Reject Null \\
\hline & Hypothesis) & Hypothesis) & Hypothesis) & Hypothesis) & Hypothesis) & Hypothesis) & Hypothesis) & Hypothesis) & Hypothesis \\
\hline
\end{tabular}

The Table no. 2 represents the empirical results of proposed research models M1, M2, and M3 for ROE, ROI and EPS. The proposed model M1 for ROE, ROI and EPS postulates the results of VA with financial performance indicators. Value Added is a very crucial ingredient for measuring the VAIC ${ }^{\text {TM }}$ performance and its constituents. The results of study demonstrate that VA has positive and significant relationship with ROI $(\beta=0.072169)$ and EPS $(\beta=0.245322)$ at $(p<0.10)$ respectively and negative association with ROE. The F-test represents the overall fitness of model. The F (Prob.) shows that proposed model for ROI and EPS is significant at $(\mathrm{p}<0.10)$.

The proposed model M2 for ROE, ROI and EPS shows the empirical relationship of VAIC $^{\text {TM }}$ with financial performance indicators. The results of study reveal that VAICTM has significant $(\mathrm{P}<0.05)$ and positive $(\beta=0.215450)$ relationship with profitability (EPS). Value Added Intellectual Coefficient (VAICTM) has significant relationship with ROI at $(\mathrm{P}<0.10)$ but this relationship is measured statistically negative $(\beta=-0.222645)$ with ROI and positive ( $\beta=0.065707)$ relationship with ROE. The proposed model M3 for ROE, ROI and EPS demonstrate the pragmatic relationship of VAIC ${ }^{\text {TM }}$ performance components (HCE, SCE and CEE) with financial indicators (ROE, ROI and EPS) of oil and gas sector.

This model represents that Human Capital Efficiency (HCE) and Structural Capital Efficiency (SCE) have a substantive positive $(\beta=0.468245 ; \beta=0.706156)$ and a significant relationship with ROE at $(\mathrm{P}<0.05)$ and a substantive negative $(\beta=-42.50043)$ but a significant relationship is observed between Capital Employed Efficiency (CEE) and ROE at $(p<0.01)$. However, M3 for ROI shows that HCE and SCE have a positive $(\beta=2.020140 ; \beta$ $=1.294653)$ and significant association with ROI at $(\mathrm{P}<0.05)$ respectively. CEE has a significant $(\mathrm{P}<0.01)$ and statistically negative $(\beta=-58.34709)$ relationship with ROI. Whereas, the M3 for EPS suggests that only SCE has positive $(\beta=0.605685)$ and significant 
$(\mathrm{P}<0.05)$ relationship with profitability (EPS). Whereas, HCE has positive $(\beta=0.173647)$ and CEE has negative $(\beta=-14.22242)$ relationship with EPS but these are not statistically significant. The values of R2 represent about $16.84 \%, 25.66 \%$ and $20.61 \%$ variations are explained by predictor's variables (HCE, SCE and CEE) in outcome variables (ROE, ROI and EPS).

\section{CONCLUSIONS}

Drawing upon a sample of panel data, this study empirically examines and explores the performance of IC and its components with financial performance indicators of oil and gas sector. There are number of classifications and measures to explore the IC performance. For that purpose the Pulic model (VAICTM) is used for IC performance. This model is being used by many researchers and practitioners in their numerous studies. VAICTM is considered as important tool to examine the value creation efficiency of tangible and intangible assets. For that purpose Value Added (VA) plays a vital role for measuring the VAIC ${ }^{\text {TM }}$ performance and its constituents. This pragmatic analysis and relationship was undertaken with the help of fixed and random effects where hausman test results suggest that random effect model is preferred on fixed effect model and $\boldsymbol{u} \boldsymbol{i}$ is uncorrelated with regressors. Intellectual Capital consider as a source of sustainable competitive advantage for firm's performance. Therefore, the results of study are consistent with previous research (Tan et al 2007; Cabrita and Vaz 2005; Tseng and Goo 2005; Maviridis 2005; Goh 2005; Rehman et al 2011; Ji-Jian et al 2006; Cabrita and Bontis 2008; Makki et al 2008; Diez et al 2010; Firer and Williams 2003; Kamukama et al 2011; Laing et al 2010) The empirical results reveal the following aspects of the relationship:

1. VA has a positive and significant relationship with ROI $(\beta=0.072169)$ and EPS $(\beta=$ $0.245322)$ at $(\mathrm{p}<0.10)$ respectively and negative association with ROE.

2. Value Added Intellectual Coefficient (VAIC $\left.{ }^{\mathrm{TM}}\right)$ has significant $(\mathrm{P}<0.05)$ and positive $(\beta=$ $0.215450)$ relationship with profitability (EPS). Value Added Intellectual Coefficient (VAICTM) has significant relationship with ROI at $(\mathrm{P}<0.10)$ but this relationship is statistically negative $(\beta=-0.222645)$ with ROI and positive $(\beta=0.065707)$ relationship with ROE.

3. Human Capital Efficiency (HCE) and Structural Capital Efficiency (SCE) perform fundamental role to enhance the Intellectual Capital Efficiency (ICE) of intangible assets of a firm performance. This study shows that HCE and SCE have a positive and significant relationship with ROE. HCE has relatively larger contribution for measuring the VAICTM performance in oil and gas sector as compare to other components of VAIC ${ }^{\text {TM}}$. This performance of HCE varies industry by industry and country to country. Due to that reason HCE has a positive and significant relationship with ROE and ROI $(\mathrm{P}<0.05)$. This means that human and structural capital perform substantive role for measuring VAICTM performance. Intellectual Capital Efficiency(ICE) which is the composition of HCE and SCE have relatively substantive contribution for measuring VAIC ${ }^{\mathrm{TM}}$ performance and to accelerate the financial performance of this sector as compare to tangible assets. HCE has relatively large contribution for measuring the ICE and VIAC ${ }^{\mathrm{TM}}$ performance as compare to other components of VAIC ${ }^{\mathrm{TM}}$ and tangible assets. Therefore, it has substantive relationship with firm's performance and its efficiency. 


\section{Limitations and Future Research of Study}

There are also certain limitations to this study. Stahle, Stahle and Aho (2011) found some critical draw backs in Ante Pulic methodology (VAIC ${ }^{\text {TM})}$ and exposed that VAIC ${ }^{\text {TM }}$ only indicates the efficiency of the firm's labour and capital investment (physical investment) and has nothing to discuss about IC performance in its true sense. The results of Pulic studies and its subsequent literature do not provide any logical deduction to support that VAIC ${ }^{\text {TM }}$ and its constituents have any relationship with firm's performance. VAIC ${ }^{\text {TM }}$ methodology has severe calculation and validity problems particularly in calculation of Intellectual Capital Efficiency (Human and Structural Efficiency) and also it does not deal with relational capital. Therefore, future researcher must consider these limitations in their studies. Regardless, validity and inherent limitations of VAICTM authors proposed that it is a suitable approach for measuring IC performance as compare to other financial and accounting approaches. Further, future researchers would get better results by increasing the size and length of period. Pulic methodology is a pure accounting technique for measuring the IC performance and use to extract data from consolidated annual reports. Whereas, different countries used different accounting practices which may influences the results.

\section{References}

[1] Bontis, N. 1998. Intellectual capital: an exploratory study that develops measures and models. Management Decision, 36(2), 63-76.

[2] Bontis, N. 2001. Assessing knowledge assets: a review of the models used to measure intellectual capital. International Journal of Management Review, 3(1), 41-60.

[3] Beodker, C., Guthrie, J. and Cuganesan, S. 2005. The strategic significance of human capital information in annual reporting. Journal of Human Resource Costing and Accounting, 8(2), 7-22.

[4] Cabrita, M. and Vaz, J. 2006. Intellectual capital and value creation: Evidence from the Portuguese Banking Industry. The Electronic Journal of Knowledge Management, 4(1), 11-20.

[5] Cabrita, M.D.R. and Bontis, N. 2008. Intellectual capital and business performance in the Portugese banking industry.Int. J. Technology Management, 43, 1-3.

[6] Calisir F., Gumussoy C.A., Bayraktaroglu A.E. and Deniz E. 2010. Intellectual capital in the quoted Turkish ITC sector. Journal of Intellectual Capital, 11(4), 537-553.

[7] Carroll, R.F. and Tansey, R.R. 2000. Intellectual capital in the new Internet economy - its meaning, measurement and management for enhancing quality. Journal of Intellectual Capital, 1(4), 296-312.

[8] Cheng M.Y., Lin J.Y., Hsiao T.Y. and Lin T.W. (2010). Invested resource, competitive intellectual capital, and corporate performance. Journal of Intellectual Capital, 11(4), 433-450.

[9] Diez, J.M., Ochoa, M.L., Prieto, M.B. and Santidrian, A. 2010. Intellectual Capital and value creation in Spanish firms. Journal of Intellectual Capital, 11(3), 348-367. 
[10] Edvinsson, L. and Malone, M.S. 1997. Intellectual Capital: Realizing Your Company's True Value By Findings Its Hidden Brainpower. Harper Collins Publishers, New York, NY.

[11] Firer, S. and Williams, S. M. 2003. Intellectual capital and traditional measures of corporate performance. Journal of Intellectual Capital, 4(3), 348-360.

[12] Fornell, C. 1992. A national customer satisfaction barometer: the Swedish experience. Journal of Marketing, 55, 1-22.

[13] Goh, P.C. 2005. Intellectual capital performance of commercial banks in Malaysia. Journal of Intellectual Capital, 6(3), 385-396.

[14] Hazlina, H. and Zubaidah, Z.A. 2008. Relationship between intellectual capital and firms' performance: evidence from public listed companies in Malaysia, Proceedings of International Accounting Business Conference, Johor Bahru, Malaysia.

[15] Ji-Jian, Z., Nai-Ping, Z. and Yu-Sheng, K. 2006-Oct. Study on intellectual Capital and Enterprise's Performance. Journal of Modern Accounting and Auditing, 2(10), 35-39.

[16] Joshi, M., Cahill D. and Sidhu J. 2010. Intellectual Capital Performance in the banking sector: An assessment of Australian owned banks. Journal of Human Resource Costing and Accounting, 14(2), 151-170.

[17] Kamath, G.B. 2008. Intellectual capital and corporate performance in Indian pharmaceutical industry. Journal of Intellectual Capital, 9(4), 684-704.

[18] Kamukama, N., Ahiauzu, A. and Ntayi, J.M. 2011. Competitive advantage: mediator of intellectual capital and performance. Journal of Intellectual Capital, 12(1), 152-164.

[19] Laing, G., Dunn, J. and Lucas, S.H. 2010. Applying the VAICTM model to Australian hotels. Journal of Intellectual Capital, 11(3), 269-283.

[20] Maditinos, D., Chatzoudes, D., Tsairidis, C. and Theriou G. 2011. The impact of intellectual capital on firms' market value and financial performance. Journal of Intellectual Capital, 12(1), 132-151.

[21] Makki, M.A.M. and Lodhi, S.A. 2008. Impact of intellectual capital efficiency on profitability (a case study of LSE25 companies).The Lahore Journal of Economics, 13(2), 81-98.

[22] Marques, D.P. and Simon, F.J.G. 2003. Validating and measuring IC in the biotechnology and telecommunication industries. Journal of Intellectual Capital, 4(3), 332-347.

[23] Maviridis, D.G. 2005. Intellectual capital Performance Determinants and globalization status of Greek Listed firms. Journal of Intellectual Capital, 6(1), 127-140.

[24] Mohiuddin, M., Najibullah, S. and Shahid, A.I. 2006. November-December. An Exploratory Study on Intellectual Capital Performance of the Commercial Banks in Bangladesh. The Cost and Management, 34(6), 40-54.

[25] OECD 1996. The Knowledge-based Economy, Organization for Economic Co-operation and Development, Paris.

[26] Prahalad, C.K. and Ramaswamy, V. 2000. Co-opting customer competence. Harvard Business Review, 78(1), 79-87. 
[27] Porter, M.E. 1999. Creating advantage. Executive Excellence, 11, 13-14.

[28] Pulic, A. 1998. Measuring the performance of intellectual potential in knowledge economy. available at: www.measuring-ip.at/OPapers/Pulic/Vaictxt/vaictxt.html

[29] Pulic, A. 2000. VAIC - an accounting tool for IC management. available at: www.measuring-ip.at/Papers/ham99txt.htm

[30] Ståhle, P., Ståhle, S. and Aho, S. 2011. Value added intellectual coefficient (VAIC): a critical analysis. Journal of Intellectual Capital, 12(4), 531-551.

[31] Stewart, T. 1997. Intellectual Capital: The New Wealth of Organizations. Doubleday/ Currency, New York, NY.

[32] Stewart, T.A. 2001. The Wealth of Knowledge: Intellectual Capital and the Twenty-first Century Organization, Doubleday, New York, NY.

[33] Sveiby, K.E. 1997. The New Organizational Wealth: Managing and Measuring Knowledge-based Assets, Berrett- Koehler, San Francisco, CA.

[35] Tovstiga, G. and Tulugurova, E. 2007. Intellectual capital practices and performance in Russian enterprises. Journal of Intellectual Capital, 8(4), 695-707.

[35] Tan, H.P., Plowman, D. and Hancock, P. 2007. Intellectual capital and financial returns of companies. Journal of Intellectual Capital, 8(1), 76-95.

[36] Tseng, C.Y. and Goo, Y.J.J. 2005. Intellectual capital and corporate value in an emerging economy: empirical study of Taiwanese manufacturers. $R \& D$ Management, 35(2), 187-201.

[37] World Bank 1998. “Knowledge for development”, World Development Report, World Bank, Washington, DC.

[38] Wood, J. 2003. Australia: an underperforming knowledge nation? Journal of Intellectual Capital, 4(2), 144-164.

[39] Wu, W.Y., Tsai, J.J., Cheng, K.Y. and Lai, M. 2006. Assessment of intellectual capital management in Taiwanese IC design companies: using DEA and the Malmquist productivity index. $R \& D$ Management, 35(2), 531-45.

[40] Yalma, A. and Coskun, M. 2007. Intellectual Capital Performance of quoted banks on the Istanbul stock exchange market. Journal of Intellectual Capital, 8(2), 256-271. 


\section{Appendix}

\begin{tabular}{|c|c|c|c|c|c|c|c|}
\hline Years & ID & Oil and Gas Sector & VAIC & HCE & SCE & CEE & VA \\
\hline 2007 & 1 & $\begin{array}{l}\text { AttockRefinary Ltd } \\
\text { (ARL) }\end{array}$ & 541.9131 & 539.083 & 1.832027 & 0.998145 & $58,969,207$ \\
\hline 2008 & 1 & $\begin{array}{l}\text { AttockRefinary Ltd } \\
\text { (ARL) }\end{array}$ & 754.3787 & 751.5514 & 1.828577 & 0.998669 & $91,577,293$ \\
\hline 2009 & 1 & $\begin{array}{l}\text { AttockRefinary Ltd } \\
\text { (ARL) }\end{array}$ & 523.0159 & 520.2994 & 1.718416 & 0.998078 & $76,448,109$ \\
\hline 2010 & 1 & $\begin{array}{l}\text { AttockRefinary Ltd } \\
\text { (ARL) }\end{array}$ & 554.0922 & 551.5921 & 1.501906 & 0.998187 & $87,994,939$ \\
\hline 2011 & 1 & $\begin{array}{l}\text { AttockRefinary Ltd } \\
\text { (ARL) }\end{array}$ & 708.0497 & 705.2304 & 1.820683 & 0.998582 & $115,967,385$ \\
\hline 2007 & 2 & $\begin{array}{c}\text { Pakistan Refinary Ltd } \\
\text { (PRL) }\end{array}$ & 765.3862 & 1240.056 & 3.983115 & 0.999194 & $57,254,941$ \\
\hline 2008 & 2 & $\begin{array}{c}\text { Pakistan Refinary Ltd } \\
\text { (PRL) }\end{array}$ & 1245.038 & 1240.056 & 3.983115 & 0.999194 & $94,686,923$ \\
\hline 2009 & 2 & $\begin{array}{l}\text { Pakistan Refinary Ltd } \\
\text { (PRL) }\end{array}$ & 959.1699 & 955.8137 & 2.357335 & 0.998954 & $76,770,953$ \\
\hline 2010 & 2 & $\begin{array}{c}\text { Pakistan Refinary Ltd } \\
\text { (PRL) }\end{array}$ & 705.3682 & 701.8914 & 2.478159 & 0.998575 & $76,475,284$ \\
\hline 2011 & 2 & $\begin{array}{c}\text { Pakistan Refinary Ltd } \\
\text { (PRL) }\end{array}$ & 844.4822 & 839.6311 & 3.852208 & 0.998809 & $96,223,409$ \\
\hline 2007 & 3 & $\begin{array}{c}\text { National Refinary Ltd } \\
\text { (NRL) }\end{array}$ & 496.3294 & 491.9975 & 3.333979 & 0.997967 & $108,226,158$ \\
\hline 2008 & 3 & $\begin{array}{c}\text { National Refinary Ltd } \\
\text { (NRL) }\end{array}$ & 574.4937 & 570.3935 & 3.101936 & 0.998247 & $144,564,521$ \\
\hline 2009 & 3 & $\begin{array}{c}\text { National Refinary Ltd } \\
\text { (NRL) }\end{array}$ & 563.2708 & 558.9917 & 3.280861 & 0.998211 & $138,926,778$ \\
\hline 2010 & 3 & $\begin{array}{c}\text { National Refinary Ltd } \\
\text { (NRL) }\end{array}$ & 534.3874 & 530.7766 & 2.612742 & 0.998116 & $134,919,688$ \\
\hline 2011 & 3 & $\begin{array}{c}\text { National Refinary Ltd } \\
\text { (NRL) }\end{array}$ & 578.578 & 574.4748 & 3.10493 & 0.998259 & $176,031,728$ \\
\hline 2007 & 4 & $\begin{array}{c}\text { Mari Gas Company } \\
\text { Limited }\end{array}$ & 61.78909 & 58.47105 & 2.335141 & 0.982898 & $21,438,470$ \\
\hline 2008 & 4 & $\begin{array}{c}\text { Mari Gas Company } \\
\text { Limited } \\
\end{array}$ & 51.27547 & 48.65228 & 1.643746 & 0.979446 & $20,696,243$ \\
\hline 2009 & 4 & $\begin{array}{l}\text { Mari Gas Company } \\
\text { Limited }\end{array}$ & 40.75542 & 38.53714 & 1.244229 & 0.974051 & $25,446,345$ \\
\hline 2010 & 4 & $\begin{array}{c}\text { Mari Gas Company } \\
\text { Limited }\end{array}$ & 41.61862 & 39.42275 & 1.221238 & 0.974634 & $26,760,281$ \\
\hline 2011 & 4 & $\begin{array}{c}\text { Mari Gas Company } \\
\text { Limited }\end{array}$ & 35.48649 & 33.40632 & 1.110105 & 0.970066 & $29,281,777$ \\
\hline 2007 & 5 & $\begin{array}{c}\text { Oil and Gas } \\
\text { Development Co. ltd }\end{array}$ & 18.78192 & 17.36454 & 0.474962 & 0.942411 & $61,430,769$ \\
\hline 2008 & 5 & $\begin{array}{c}\text { Oil and Gas } \\
\text { Development Co. 1td }\end{array}$ & 18.57162 & 17.09693 & 0.533176 & 0.94151 & $80,279,472$ \\
\hline 2009 & 5 & $\begin{array}{c}\text { Oil and Gas } \\
\text { Development Co. 1td }\end{array}$ & 13.90863 & 12.58047 & 0.407647 & 0.920512 & $72,558,106$ \\
\hline
\end{tabular}




\begin{tabular}{|c|c|c|c|c|c|c|c|}
\hline 2010 & 5 & $\begin{array}{c}\text { Oil and Gas } \\
\text { Development Co. 1td }\end{array}$ & 13.48893 & 12.19316 & 0.37778 & 0.917987 & $86,461,733$ \\
\hline 2011 & 5 & $\begin{array}{c}\text { Oil and Gas } \\
\text { Development Co. 1td }\end{array}$ & 15.41158 & 14.02498 & 0.457897 & 0.928699 & $119,867,177$ \\
\hline 2007 & 6 & Pakistan State Oil (PSO) & 209.9867 & 203.5291 & 5.462475 & 0.995087 & $408,250,702$ \\
\hline 2008 & 6 & Pakistan State Oil (PSO) & 242.4765 & 236.9372 & 4.543586 & 0.995779 & $577,535,268$ \\
\hline 2009 & 6 & Pakistan State Oil (PSO) & 253.7426 & 248.1023 & 4.644287 & 0.995969 & $712,533,301$ \\
\hline 2010 & 6 & Pakistan State Oil (PSO) & 277.3676 & 272.0663 & 4.304912 & 0.996324 & $870,658,805$ \\
\hline 2011 & 6 & Pakistan State Oil (PSO) & 230.3645 & 225.6862 & 3.682803 & 0.995569 & $967,374,435$ \\
\hline 2007 & 7 & $\begin{array}{l}\text { Attock Petroleum Ltd } \\
\text { (APL) }\end{array}$ & 567.6575 & 561.1221 & 5.537164 & 0.998218 & $49,744,594$ \\
\hline 2008 & 7 & $\begin{array}{l}\text { Attock Petroleum Ltd } \\
\text { (APL) }\end{array}$ & 551.9415 & 547.0843 & 3.859059 & 0.998172 & $59,866,884$ \\
\hline 2009 & 7 & $\begin{array}{l}\text { Attock Petroleum Ltd } \\
\text { (APL) }\end{array}$ & 490.3477 & 485.4985 & 3.851228 & 0.99794 & $70,363,296$ \\
\hline 2010 & 7 & $\begin{array}{c}\text { Attock Petroleum Ltd } \\
\text { (APL) }\end{array}$ & 530.4566 & 525.0469 & 4.411636 & 0.998095 & $94,597,175$ \\
\hline 2011 & 7 & $\begin{array}{l}\text { Attock Petroleum Ltd } \\
\text { (APL) }\end{array}$ & 608.8143 & 602.643 & 5.172956 & 0.998341 & $126,635,785$ \\
\hline 2007 & 8 & Pakistan Petroleum Ltd & 14.31134 & 12.9166 & 0.472162 & 0.92258 & $23,782,400$ \\
\hline 2008 & 8 & Pakistan Petroleum Ltd & 14.84064 & 13.4296 & 0.485506 & 0.925538 & $29,627,145$ \\
\hline 2009 & 8 & Pakistan Petroleum Ltd & 17.05004 & 15.62631 & 0.487725 & 0.936005 & $40,440,276$ \\
\hline 2010 & 8 & Pakistan Petroleum Ltd & 15.34677 & 14.00087 & 0.417321 & 0.928576 & $44,895,211$ \\
\hline 2011 & 8 & Pakistan Petroleum Ltd & 17.07234 & 15.64666 & 0.489582 & 0.936089 & $60,772,257$ \\
\hline 2007 & 9 & Shell Pakistan Ltd & 130.5232 & 125.2291 & 4.302083 & 0.992015 & $125,672,142$ \\
\hline 2008 & 9 & Shell Pakistan Ltd & 145.7704 & 140.9523 & 3.825241 & 0.992905 & $151,727,656$ \\
\hline 2009 & 9 & Shell Pakistan Ltd & 111.7091 & 105.6608 & 5.057793 & 0.990536 & $170,213,604$ \\
\hline 2010 & 9 & Shell Pakistan Ltd & 132.7555 & 126.1373 & 5.626163 & 0.992072 & $216,593,263$ \\
\hline 2011 & 9 & Shell Pakistan Ltd & 170.8278 & 164.9395 & 4.89436 & 0.993937 & $240,602,236$ \\
\hline
\end{tabular}

